\title{
Studies on wall painting materials and techniques at two historic buildings in Gyantse, Tibet
}

\author{
Xinhui Yang, Xinyan Ji, Yongkang Cao ${ }^{*}$ and Taoyi Yu
}

\begin{abstract}
This paper presents a scientific examination of wall paintings at two nonmonastic sites in Gyantse, Tibet: Gazhi Lhakang, which is a family temple built in the mid-eighteenth century by local aristocrats, and the Lotso Residence, which was occupied by Nepalese merchants in the early twentieth century. Samples were analyzed with optical microscopy, scanning electron microscopy with energy-dispersive X-ray spectroscopy, Raman spectroscopy, and X-ray diffraction. Two phases of painting — an early phase and a late phase — were identified in Gazhi Lhakang, including three distinct types of mural stratigraphy. The earlier phase features an unusual technique known as "paperhanging", wherein the pigments were applied on a layer of Tibetan paper glued to the wall. The later phase at Gazhi Lhakang and the painting of the Lotso Residence feature a relatively simple wall treatment with fewer coating layers and no ground layer. A typical mixture of clay and sand was used for the coating layers, while the structure slightly varied from what has been described in the literature. The techniques of powder embossing, gilding, and gold outlining were adopted in both buildings. The metallic material found at Gazhi Lhakang is a gold-silver alloy, while copper was used as imitation gold at the Lotso Residence. Mineral pigments, such as azurite, malachite, orpiment, cinnabar, and iron oxide, were used for both phases of Gazhi Lhakang. Modern synthetic pigments, such as chrome yellow, emerald green, and synthetic ultramarine, were used for the Lotso Residence, indicating that it was painted after the mid-nineteenth century.
\end{abstract}

Keywords: Tibet, Wall painting, Synthetic pigments, Gilding

\section{Introduction}

Located approximately $6 \mathrm{~km}$ to the northwest of Gyantse, Tibet, Gazhi Lhakang is a temple that was established in 1746 by a family known as Gazhi or Doring, which was one of the most privileged aristocratic families in Tibet [1-3]. Facing east, the two-story temple features a square plan with 36 columns; hence, this temple is in the medium scale among all Tibetan temples but is a very large "private" temple. The four walls are decorated with murals, which now comprise two distinct phases. The earlier phase, which is marked by severe damage and a darkened surface, contains large polychrome images of Buddhist deities and the patrons over a red background bearing small figures painted in golden lines. This

\footnotetext{
*Correspondence: ahc@sjtu.edu.cn

International Research Center for Architectural Heritage Conservation, Shanghai Jiao Tong University, Shanghai, China
}

earlier phase was probably completed when the temple was built. Although existing historical accounts of the Gazhi family provide no detail of these murals, Tibetan researcher Kalsang Norbu [4] identifies the murals as Old Menri style paintings with a special technique, which involves applying a paper layer on the wall and finishing the images on the paper (Fig. 1a). This style was founded by the master painter Menla Dondrub (ca. late fifteenthearly sixteenth century) and was popular in Central Tibet [5]. The later phase, which appears to be the result of restoration, exists only on the west wall. The mural quality of this phase does not compare to that of the earlier phase.

The Lotso Residence is a two-story building located in the old town of Gyantse. Although no written historical account has been found for this building, some locals suggest that it housed the Nepalese "Chamber of Commerce" in the first half of the twentieth century. By that time, Gyantse was one of the most important commercial 


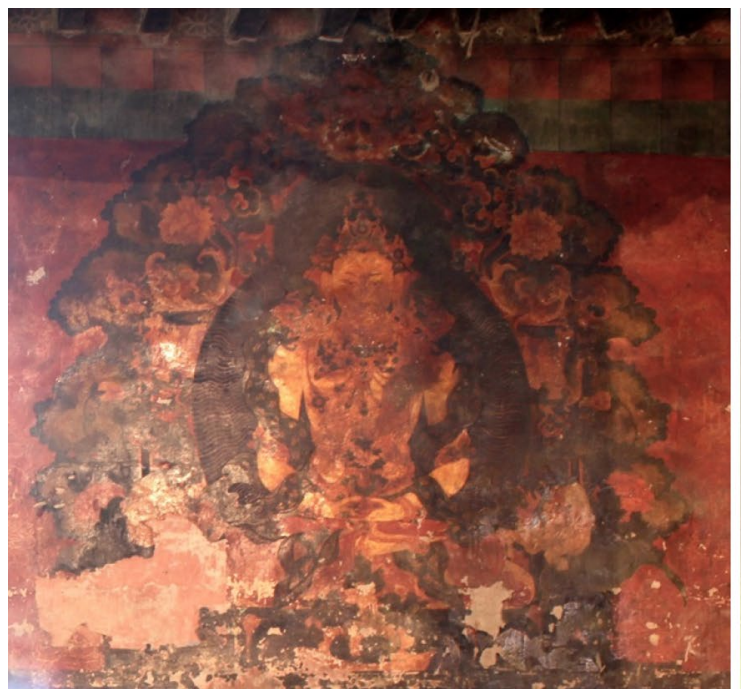

a

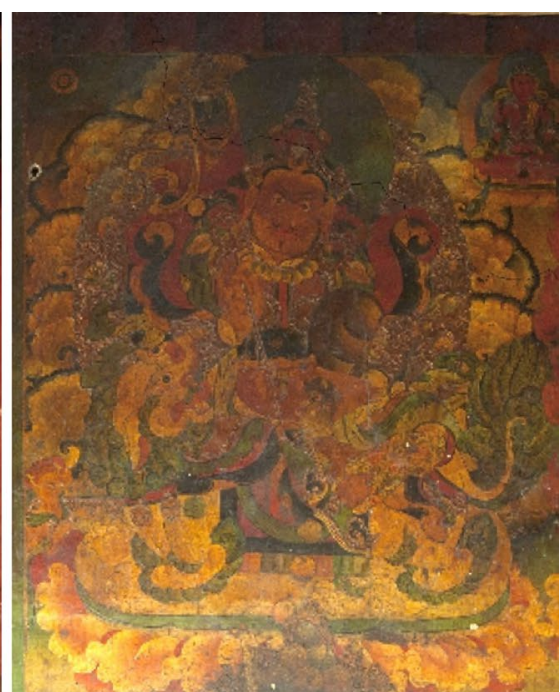

b

Fig. 1 Section of wall paintings: a a polychrome Buddha (earlier phase) at Gazhi Lhakang and $\mathbf{b}$ a guardian at the Lotso Residence

centers of Tibet, with trade routes connecting to Nepal and India [6]. On the second floor of the Lotso Residence, there is a shrine room decorated with murals comprising several polychrome Buddhist guardians (Fig. 1b). Surrounding these guardians is a black background, on which a variety of motifs, including animals and sacred objects, are painted in yellow lines. The murals show no evidence of restoration and can be identified as the New Menri style (a variation of the Old Menri style), which was created by artist Choying Gyatso in the seventeenth century [5]. The exact date of the house and the murals remains unknown. According to the locals, the murals were painted before 1959, the year when the building stopped serving Nepalese merchants and became a residence for locals.

Murals, which commonly exist in religious buildings, constitute a significant part of Tibetan cultural heritage. A rich amount of scholarly work has been devoted to the history, iconography, and aesthetic values of murals. On the other hand, many Tibetan murals are in poor condition due to some intrinsic features of the materials and, more importantly, the lack of maintenance. Researchers have started to focus on the analysis of materials and techniques as the first and most crucial step for conservation and restoration [7]. Recent publications include case studies of the Potala Palace, Norbulingka, and a few prominent monasteries, such as Jokhang, Shalu, Drepung, and Palkor, wherein some unique characteristics of Tibet paintings have been revealed [8-15]. The wall painting in a fifteenth-century Buddhist temple in Nepal have also been examined [16].
During 2015-2016, the International Research Center for Architectural Heritage Conservation of Shanghai Jiao Tong University conducted a heritage documentation project in Gyantse. The murals at both Gazhi Lhakang and the Lotso Residence were examined, during which pollution, detachment, and cracking were observed. In this light, the current study, which incorporates on-site observation and laboratory analysis of the pigments, serves several purposes. The first purpose of this study is to provide a better understanding of the local wall painting techniques by comparing these techniques with "common" Tibetan practices documented in the literature $[17,18]$. The Lotso Residence provides an example of murals outside religious institutions that received little attention. The second purpose of this study is to suggest a possible dating for the murals if any modern synthetic pigments (which emerged in the nineteenth century or later) were identified. The third purpose of this study is to collect data for future conservation interventions.

\section{Materials and methods \\ Sampling}

The sampling strategy was developed according to the composition of the murals. At both Gazhi Lhakang and the Lotso Residence, a typical Tibetan composition was adopted by the artists. This composition horizontally divides the wall into three registers (Fig. 2). The upper register bears the "contents" of the mural, such as images of buddhas, bodhisattvas, and guardians. At the top of the wall, there is a decorative band featuring "imitation curtains." In some cases (such as at the Lotso Residence), 


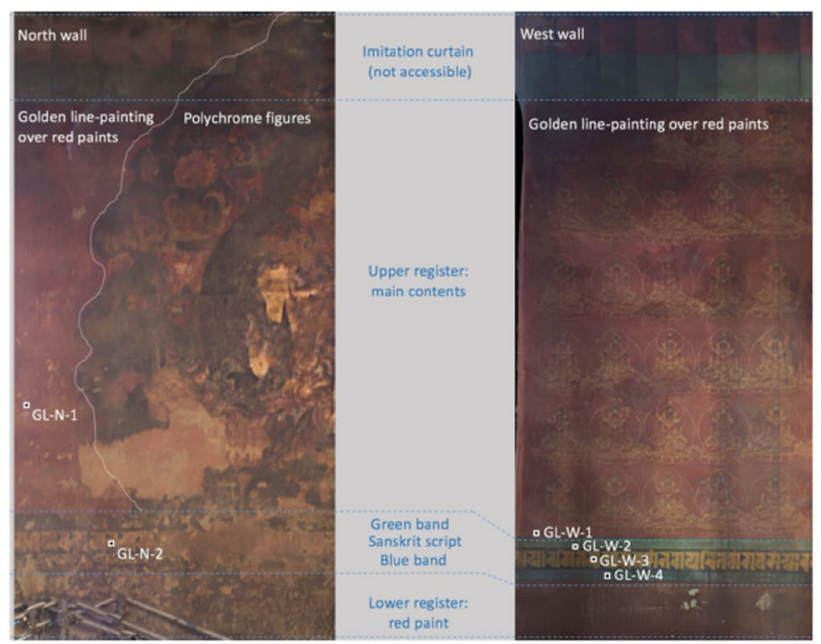

a
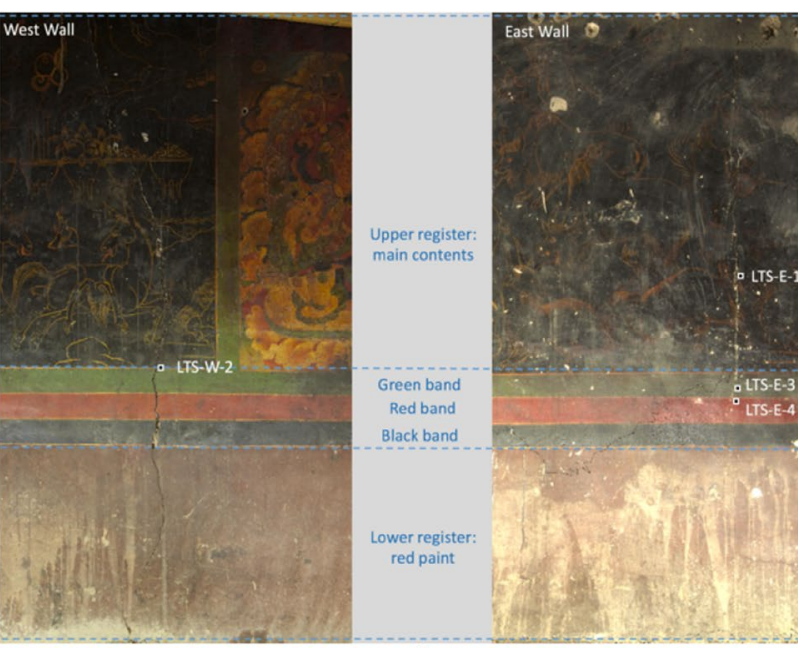

b

Fig. 2 Sample location: a Gazhi Lhakang and b Lotso Residence

the major figures are "framed" by a color band, which merges with the three horizontal color bands above the lower register. These bands are sometimes filled with decorative motifs [17].

At Gazhi Lhakang, paintings of both the earlier and the later phase contain Sanskrit spells (written in the Ranjana script) painted within the middle band. According to Chen and Zhang [19], applying Sanskrit spells to wooden structures and murals is a common practice among Buddhist temples in Tibet, Mongolia, and China proper. It is worth noting that the letters of the earlier phase were gilded and outlined using a special technique called "powder embossing" (lifen 励粉), which created a raised decoration (Fig. 3a). The lower register, which is the least important register, is usually painted with a solid color.
In the two cases analyzed here, deep red was adopted for the lower register.

To limit the damage caused by sampling, all samples were taken from cracked or detached areas. The locations of bulk samples (four from the Lotso Residence and six from Gazhi Lhakang) are shown in Fig. 2. Moreover, since the paper layer had already shown detachment, bulk sampling in these areas was not possible. Hence, powder samples of three different colors, deep blue (GLE-1), light blue (GL-E-2), and green (GL-S-1), were collected from the polychrome parts of the earlier paintings. Pieces of the paper (approximately $1 \mathrm{~cm}$ by $1 \mathrm{~cm}$ ) were cut off, and the pigments were removed from the surface. However, due to the difficulty of separating the pigments from the gesso layer below, the mix of these two layers

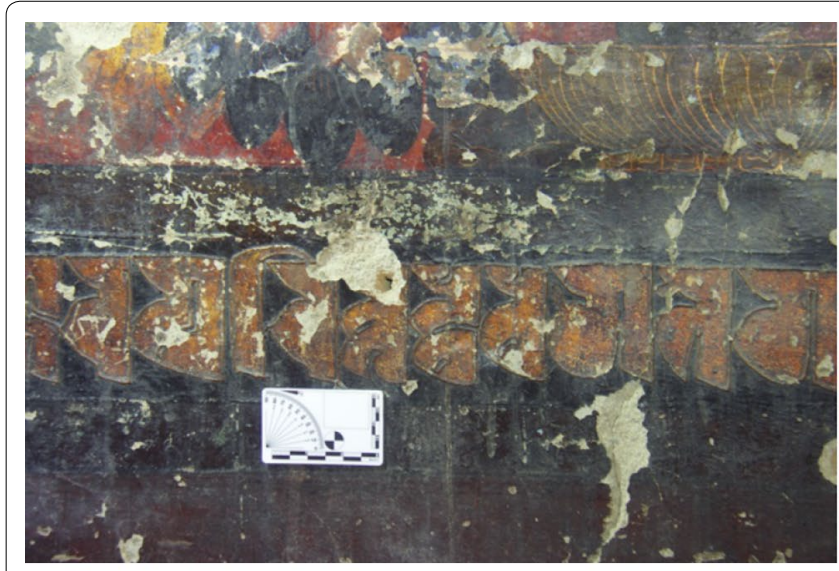

a

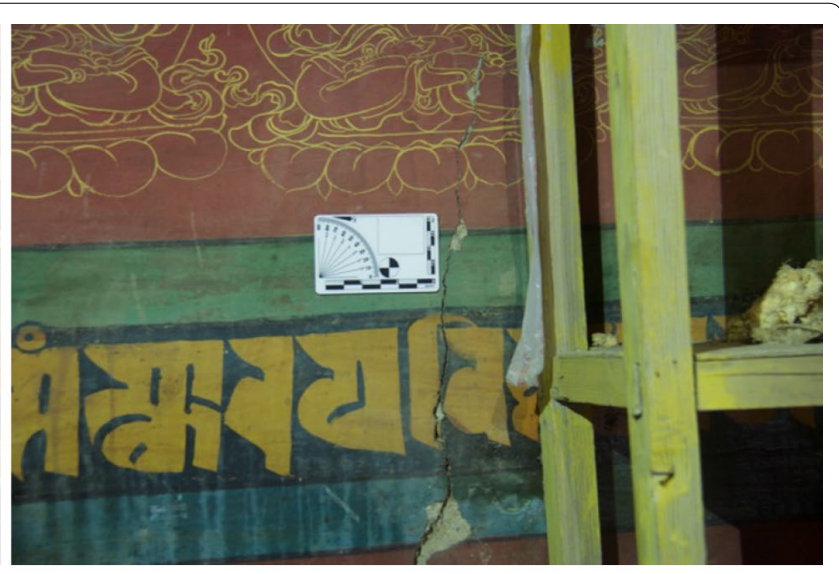

b

Fig. 3 Sanskrit spells at Gazhi Lhakang: a the earlier phase with "powder embossing" and $\mathbf{b}$ the later phase without "powder embossing" 
was analyzed together in the laboratory. The coating layer sample (GL-S-2) was taken from under the paper.

\section{Sample preparation and instrumentation Optical microscopy}

The bulk samples were mounted in an epoxy resin support and polished for cross-sectional analysis. Observation and photography of the stratigraphy were performed using a Zeiss Axio Imager A1m microscope. Based on the characteristics of each sample, the samples were observed under various magnifications, from $50 \times$ to $500 \times$. Some pigment particles were dispersed on a slide and analyzed with a Leica DM4000M microscope under $500 \times$.

\section{Scanning electron microscopy with energy-dispersive X-ray spectroscopy (SEM-EDS)}

After optical microscopy, the surface of each sample containing a metallic layer was coated with $\mathrm{Au}$ or Pt for SEM-EDS analysis. This analysis was conducted using JEOL JSM-7800F Prime equipped with a SmartSEM system for data collection. The range of magnification is $95 \times$, and the excitation voltage is $15 \mathrm{kV}$. Energy spectrum analysis was conducted using a Thermo Scientific NORANTM System spectrometer.

\section{Raman spectroscopy}

The cross-section samples were repolished to remove the coated layer and analyzed with a Senterra R200-L Raman microscope. The laser wavelengths employed were 532 and $785 \mathrm{~nm}$, with an acquisition time of $20 \mathrm{~s}$, and 4-6 acquisitions per spectrum. Black, blue and green pigments were analyzed at $532 \mathrm{~nm}$. Red, yellow and orange pigments were tested at $785 \mathrm{~nm}$. The power on the samples was kept as low as possible with suitable data achievable with powers of $5 \mathrm{~mW}$.

\section{$X$-ray diffraction (XRD)}

The powder samples were ground and mounted on a glass sample holder. Due to the amount of material collected, the samples did not fill the entire hollow space of the holder but were gathered at the center. Since it was impossible to separate the pigments from the light-yellow layer underneath (above the paper), the analyzed samples were a mix of these two layers. A Bruker D8 Advance Da Vinci X-ray Diffractometer was used for the analysis. The X-ray emitter maximum output power was $3 \mathrm{~kW}$, the tube voltage was $80 \mathrm{kV}$, the tube current was $60 \mathrm{~mA}$, the target was $\mathrm{Cu}$, and the focus size was $0.5 \mathrm{~mm} \times 10 \mathrm{~mm}$. The measurement range was $100 \leq 200 \leq 800$, with a scanning speed of $100 / \mathrm{min}$.

\section{Results and discussion}

Structure of Tibetan murals described in the literature Generally, the structure of Tibetan murals consists of four parts (from inside to outside): the support, the coating layers, the ground layer, and the paint layer (as shown in the diagram in Table 1). The common wall treatment procedure has been described in the literature [17, 20]. First, the wall is covered with a coating layer (1.5 to $3 \mathrm{~cm}$ thick) containing earth and coarse sand, to which chopped straw may be added to prevent cracking. Then, a second coating layer (approximately $1 \mathrm{~cm}$ thick), which contains finer sand and cattle hair, is applied. The third layer (less than $1 \mathrm{~cm}$ thick) comprises very fine sand and a unique material called arga in Tibetan.

There is a terminological inconsistency concerning arga in recent scholarship. Some conservators use the term arga as the name of a specific kind of clay, which mainly consists of calcite, kaolinite, potassium feldspar, illite, and quartz, although the composition may vary for different areas $[9,10,21]$. Other researchers use the term for a mixture. André Alexander [22] describes arga as "tamped and polished earth with high lime content." A study on the arga used at the Palkor Monastery in Gyantse identified calcite, quartz, and some compounds containing $\mathrm{Al}$ and $\mathrm{Mg}$ [23]. In terms of the characteristics of arga, Zhao [24] suggests that arga is heavy and poorly adhesive, which is one of the reasons that Tibet wall paintings commonly display cracks and detachment.

The third coating layer is smoothed using a pebble. Then, a layer of light-red glue is applied to the surface, followed by a layer of white or light-yellow gesso, which is called dam in Tibetan and is often referred to as the "white powder layer" in Chinese literature [17, 25]. The gesso serves as the ground for painting. However, variations from the above common practice were observed at Gazhi Lhakang and the Lotso Residence, as discussed below (Table 1).

\section{On-site observation \\ Support}

Different materials were used for support at the two sites. At the Lotso Residence, the walls were constructed in an ordinary way, similar to most of the other traditional residences in Gyantse. The walls are made of adobe bricks, which are as thick as $40 \mathrm{~cm}$ in the second story (usually the walls are thicker in the first story). The bricks are produced by mixing clay, gravels, and plant fibers on-site and laid until dry (without firing). The external surfaces are coated using a mixture of clay and lime and painted with lime wash [20]. In contrast, Gazhi Lhakang was modeled after high-level monastic temples, although it was a family temple. The walls were made of stone, with alternating 
Table 1 Schematic diagrams of cross-sections

\begin{tabular}{|c|c|c|c|c|c|}
\hline Location & $\begin{array}{l}\text { General } \\
\text { practice in Tibet }\end{array}$ & $\begin{array}{l}\text { Lotso } \\
\text { Residence }\end{array}$ & $\begin{array}{l}\text { Earlier phase at } \\
\text { Gazhi Lhakang } \\
\text { with the paper } \\
\text { layer }\end{array}$ & $\begin{array}{l}\text { Earlier phase at } \\
\text { Gazhi Lhakang } \\
\text { without the } \\
\text { paper layer }\end{array}$ & $\begin{array}{l}\text { Later phase at } \\
\text { Gazhi Lhakang }\end{array}$ \\
\hline $\begin{array}{l}\text { Schematic } \\
\text { diagrams }\end{array}$ & 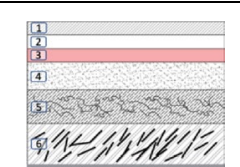 & (1) & 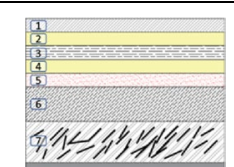 & 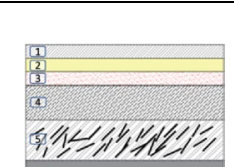 & 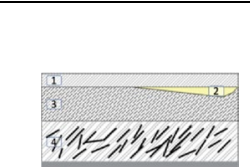 \\
\hline Layers & $\begin{array}{l}1 \text { - pigment } \\
2 \text { - white } \\
\text { powder layer } \\
\text { (white or } \\
\text { yellow) } \\
3 \text { - light-red } \\
\text { glue } \\
4 \text { - third coating } \\
\text { layer } \\
5 \text { - second } \\
\text { coating layer } \\
6 \text { - first coating } \\
\text { layer } \\
7 \text { - support } \\
\text { body }\end{array}$ & $\begin{array}{l}1 \text { - pigment } \\
2 \text { - second } \\
\text { coating layer } \\
3 \text { - first coating } \\
\text { layer } \\
4 \text { - support } \\
\text { body }\end{array}$ & $\begin{array}{l}1 \text { - pigment } \\
2 \text { - gesso (light- } \\
\text { yellow) } \\
3 \text { - paper layer } \\
4 \text { - gesso (light- } \\
\text { yellow) } \\
5 \text { - third coating } \\
\text { layer } \\
6 \text { - second } \\
\text { coating layer } \\
7 \text { - first coating } \\
\text { layer } \\
8 \text { - support } \\
\text { body }\end{array}$ & $\begin{array}{l}1 \text { - pigment } \\
2 \text { - gesso (light } \\
\text { yellow) } \\
3 \text { - third coating } \\
\text { layer } \\
4 \text { - second } \\
\text { coating layer } \\
5 \text { - first coating } \\
\text { layer } \\
6 \text { - support } \\
\text { body }\end{array}$ & $\begin{array}{l}1 \text { - pigment } \\
\text { - } 2 \text { - yellowish } \\
\text { material for } \\
\text { filling up } \\
3 \text { - possible } \\
\text { second coating } \\
\text { layer } \\
4 \text { - possible first } \\
\text { coating layer } \\
5 \text { - support } \\
\text { body }\end{array}$ \\
\hline
\end{tabular}

layers of flagstones and block stones. The bottom part of the walls reaches almost $1 \mathrm{~m}$ in thickness.

\section{Coating layers}

Observations on the earlier murals at Gazhi Lhakang through damaged areas revealed three coating layers.
The bottom layer, exhibiting a medium-yellow color, is up to several centimeters thick and consists of coarse sand, earth, and chopped straw (Fig. 4a). The use of chopped straw is probably related to the fact that Gyantse was one of the most important agricultural areas in Tibet, and straw was highly available [6]. The second coating layer

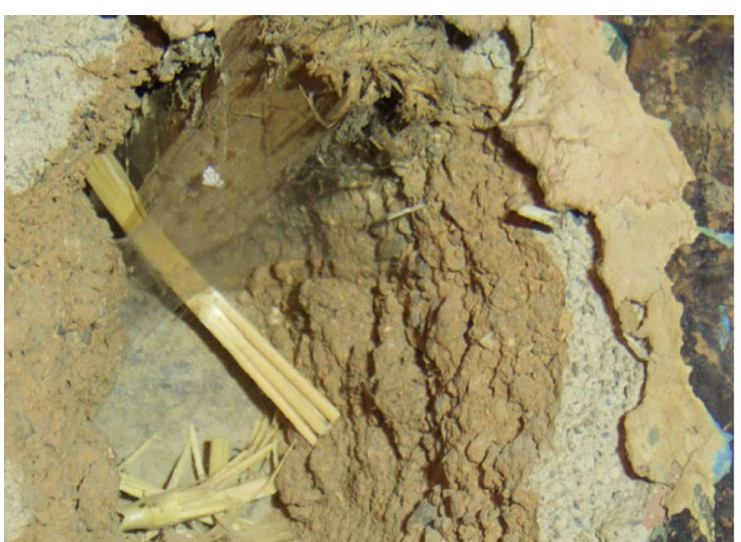

a

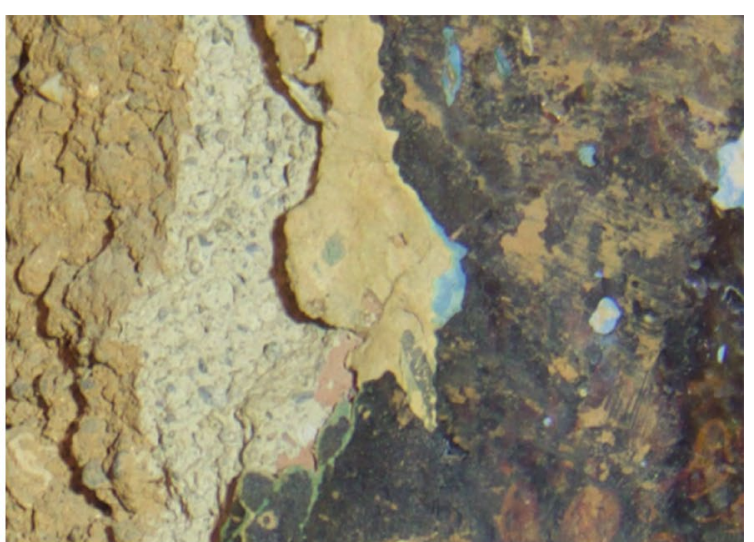

b

Fig. 4 Photos of the detached part from the upper part of early Gazhi Lhakang: a the coating layers and the paper layer; $\mathbf{b}$ light-red and light-yellow preparation layers 
shows a much brighter color and is approximately $0.5 \mathrm{~cm}$ thick; moreover, this layer is composed of finer sand and possibly clay. The third layer is an extremely thin and reddish layer (Fig. 4b) with a very smooth surface. Thus, the murals do not contain a third "fine" coating that resembles the one described in the literature. However, the "coarse" and "medium" coating layers are consistent with common practice, although no animal hair was observed.

The murals of Gazhi Lhakang later phase and the Lotso Residence were in a better conservation condition. For the Gazhi Lhakang later phase, only one coating layer was visible in small detached areas (Fig. 5a). The color and texture of this layer are similar to those of the second coating layer under the earlier paintings. For the Lotso Residence, a crack reveals that two coating layers were used (Fig. 5b). More details about their stratigraphy will be discussed later in the section of laboratory analysis.

\section{Ground layer and the paper}

The treatment of the ground layer at the earlier phase of Gazhi Lhakang can be divided into two kinds: with or without paper (Table 1). It is clear that the paper layer was applied to the upper register for the large images, but the exact boundary remains unknown. The paper (as seen in Fig. 4a) is light brown in color and made of coarse fibers, which Kalsang Norbu suggests is a local Tibetan paper [4]. Two gesso layers are visible. As mentioned above in the sampling section, one gesso layer is right below the pigment and above the paper. The function of this layer seems to be creating a light-yellow smoothed surface for the actual painting. The other gesso layer is located below the paper, and its function remains uncertain.

\section{Laboratory analysis \\ Stratigraphy}

The sample GL-N-1 (Fig. 6a) was taken from a Sanskrit letter (without paper) in the earlier phase of Gazhi Lhakang. Above the coating layers, the stratigraphy shows (1) a layer of gesso, (2) a layer of paint in orange-yellow color, (3) the "powder embossing" of the outlines of the Sanskrit letter, which appears to be approximately $400 \mu \mathrm{m}$ high and $1500 \mu \mathrm{m}$ wide, (4) another layer of gesso, (5) a layer of metal foil (no thicker than $15 \mu \mathrm{m}$ ), and (6) a blue paint that only exists outside the shape of the letter. This stratigraphy indicates how the Sanskrit band was painted: the artists did not paint yellow letters over a blue background; instead, they used the blue paint to "frame" the shape of the letters.

The samples GL-N-2 and LTS-E-4 were taken from the golden line painting area at Gazhi Lhakang and the Lotso Residence, respectively. The cross-sections of these samples show that the metallic paint was directly applied on top of the background pigment (Fig. 6b, c), but there is a sharp contrast in the thickness of the metallic layer.

Cross-sectional observation of the bulk samples taken from the west wall (the later phase) of Gazhi Lhakang revealed no distinct gesso layer between the pigments and the coating. However, some yellowish material, which seems to be gesso, was used to smooth the coating (Fig. 7a). The existence of a red layer in all samples of this phase indicates that first red paint was applied to the entire upper and middle registers. Afterwards, the three color bands were painted over the red layer. The stratigraphy of GL-W-3 exhibits a thin blue layer over a relatively thick and even yellow layer. The yellow is the Sanskrit letters (Fig. 5a) drawn on the red paint, and blue

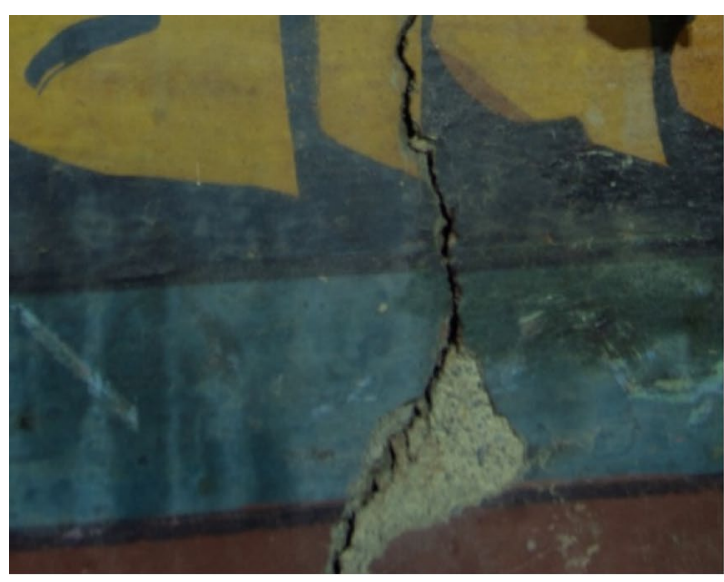

a

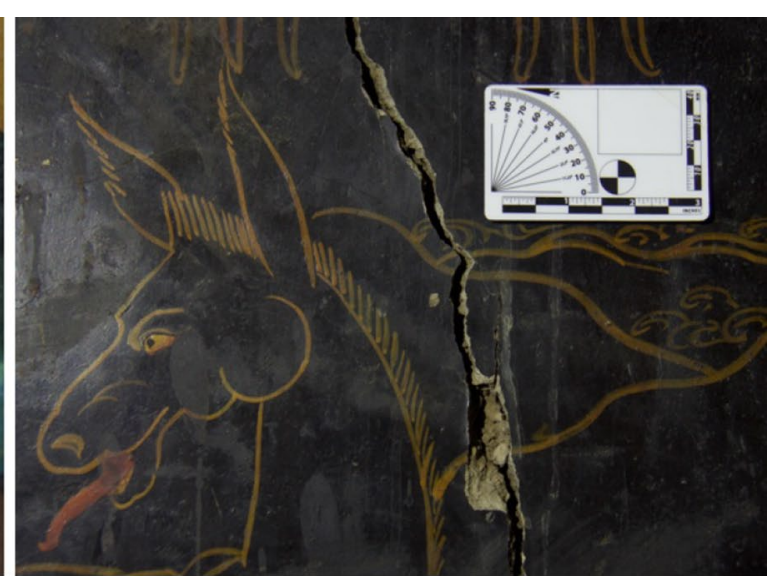

b

Fig. 5 Damaged parts of a the Gazhi Lhakang later phase and $\mathbf{b}$ the Lotso Residence 


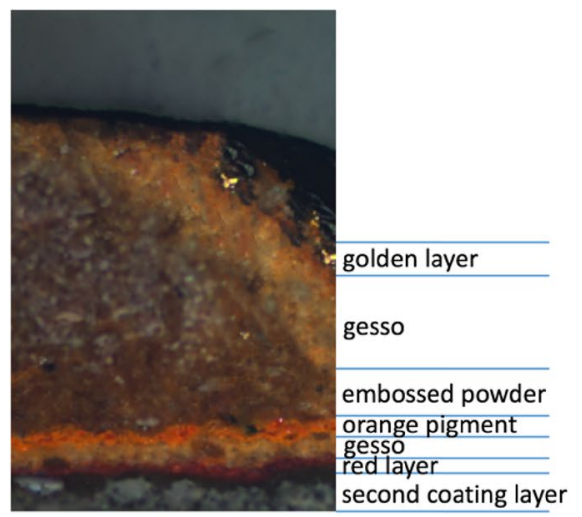

a

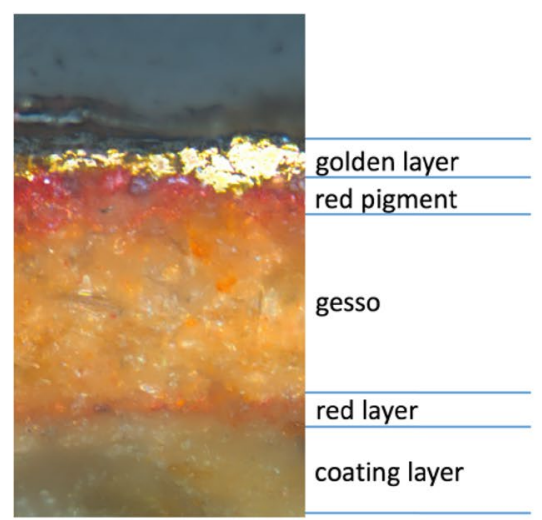

b

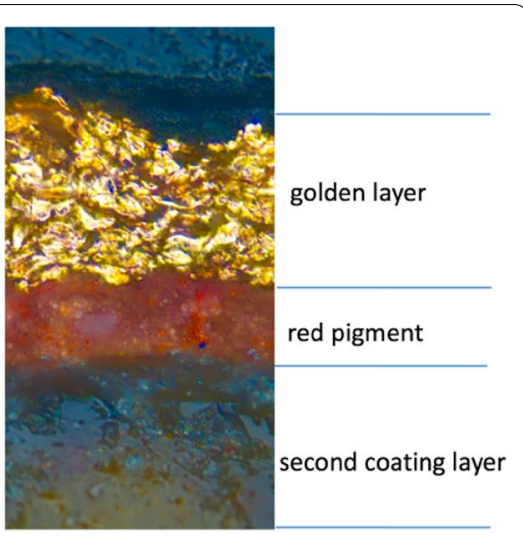

c

Fig. 6 Cross-sections with metallic materials: a GL-N-1 (200x), b GL-N-2 (500x) and c LTS-E-4 (500x)

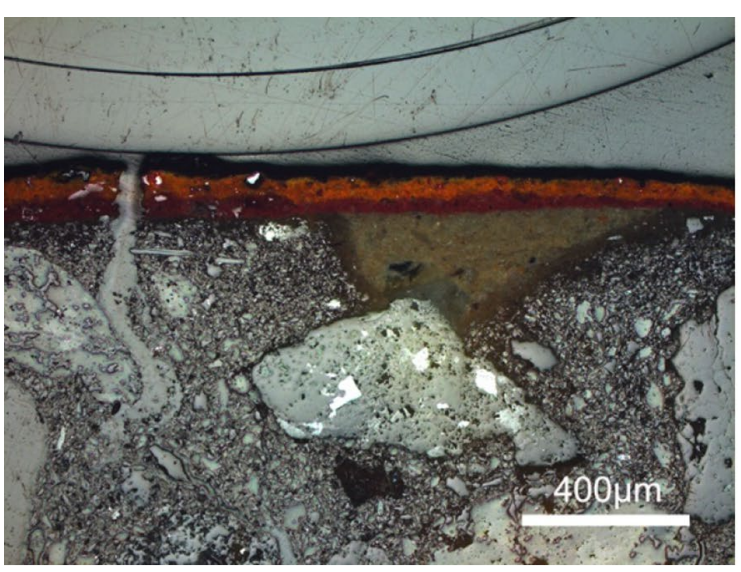

a

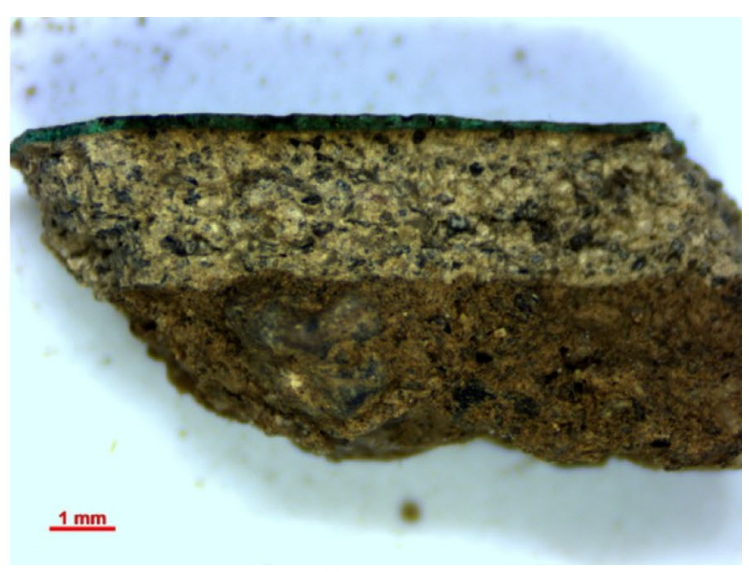

b

Fig. 7 Cross-sections under lower magnification: a GL-W-3 from Gazhi Lhakang late phase and $\mathbf{b}$ LTS-E-3 from the Lotso Residence

was applied to cover the rest of the band, which is a process similar to the earlier phase.

The observation under lower magnification shows that two coatings were applied for the paintings at the Lotso Residence (Fig. 7b). The lower coating contains coarse sand, while the upper coating contains finer sand and exhibits a lighter color. The thickness of the upper coating is 0.3 to $0.5 \mathrm{~cm}$. No ground layer was observed. This practice of painting directly on the coating was also found in the Drepung and Palkor Monasteries [12, 14]. At the Lotso Residence, the thicknesses of the different pigment layers vary greatly. The thinnest black-and-yellow layer (LTS-E-1) is thinner than $10 \mu \mathrm{m}$, and the thickest green layer (LTS-E-3) is thicker than $200 \mu \mathrm{m}$. This difference might be due to the texture of each pigment.

\section{Materials of the coating and ground layers}

The XRD analysis of the coating sample from Gazhi Lhakang (GL-S-2) shows the presence of quartz, calcite, and illite, indicating the material to be a mixture of clay, sand, and possibly lime. These components are similar to those found at the Palkor Monastery [23], which is dated to the fifteenth century, confirming that using arga (here the term denotes the mixture, not the clay) was a local building tradition.

In the ground layers, a relatively high percentage of $\mathrm{Si}, \mathrm{O}$, and $\mathrm{C}$ and some $\mathrm{Fe}, \mathrm{Al}, \mathrm{Mg}, \mathrm{K}$, and $\mathrm{Ca}$ were identified by SEM-EDS, suggesting the presence of clay minerals and very likely quartz. SEM-EDS also confirmed that the yellowish "smoothing" material found in the later phase of Gazhi Lhakang was gesso. It is possible that during the restoration of the west wall, the original painting layers were removed until the surface of the second coating layer. Due to limitations in time or budget, instead of reapplying all the coatings, the artists only used a small amount of gesso to smooth the surface before painting (for a diagram, see Fig. 4e). 


\section{Pigment identification}

The common materials used for the ground and pigment layers in Tibetan wall paintings are fundamentally similar to those used for Thangka paintings. Previous scholarship has summarized the most important mineral pigments, including azurite $\left(\mathrm{Cu}_{3}\left(\mathrm{CO}_{3}\right)_{2}(\mathrm{OH})_{2}\right)$, malachite $\left(\mathrm{Cu}_{2} \mathrm{CO}_{3}(\mathrm{OH})_{2}\right)$, lapis lazuli/ultramarine $\left(\mathrm{Na}_{6} \mathrm{Al}_{4} \mathrm{Si}_{6} \mathrm{~S}_{4} \mathrm{O}_{20}\right)$, cinnabar/vermillion $(\mathrm{HgS})$, minium orange $\left(\mathrm{Pb}_{3} \mathrm{O}_{4}\right)$, orpiment $\left(\mathrm{As}_{2} \mathrm{~S}_{3}\right)$, realgar $\left(\mathrm{As}_{4} \mathrm{~S}_{4}\right)$, yellow ochre $(\mathrm{FeO}(\mathrm{OH}))$, earth white (calcium compounds), and carbon black $[26,27]$. In addition, iron red $\left(\mathrm{Fe}_{2} \mathrm{O}_{3}\right)$ is widely used for painting walls (including the exterior walls for significant buildings) due to its low price.

Tables 2 and 3 show the results of pigment identification by SEM-EDS and Raman spectroscopy. Organic dyes, which are often used for shading over base colors, cannot be identified with the current method.

Red layers SEM-EDS examination of red pigments (the base color layer) in the later paintings of Gazhi Lhakang revealed a high content of $\mathrm{Fe}$, indicating the existence of iron red. Raman microscopy of GL-W-1 confirmed this result but also detected realgar $\left(\mathrm{As}_{4} \mathrm{~S}_{4}\right)$ in the red layer. The red color serving as background for gold outlining in the earlier phase (GL-N-2) was identified as cinnabar. A mix of cinnabar and iron red was used for the red color band at the Lotso Residence (LTS-E-4). Although realgar and cinnabar show a brighter and richer color than iron red, iron red is less expensive. The mixing of pigments was probably for cost-saving reasons.

Blue pigments X-ray diffraction analysis of dark-blue and light-blue powder samples (GL-E-1 and GL-E-2) from the earlier phase of Gazhi Lhakang suggests that both pigments are azurite. Their different shades probably resulted from "progressive sedimentation," a traditional pigment producing process applied to the most common blue and green pigments, azurite and malachite. Pigment-makers first stir up powdered minerals in water. After the darker and heavier particles have settled to the bottom, the water is poured into another dish to separate the darker particles from the lighter ones. This process is then repeated in two parts, resulting in four kinds of blue, each with a unique name in Tibetan [27].

In the blue layer of GL-W-4 (the later phase), a high percentage of $\mathrm{Cu}, \mathrm{C}$, and $\mathrm{O}$ was identified by SEMEDS, while no $\mathrm{Na}, \mathrm{Cl}$, or $\mathrm{Al}$ was present. This result also points to azurite. The blue particles of LTS-E-3 and LTS-W-2 can be identified as lapis lazuli/ultramarine, as the main elements were $\mathrm{Na}, \mathrm{Al}, \mathrm{Si}$, and $\mathrm{S}$ without the presence of $\mathrm{Cu}$. Further examination of the pigment dispersion suggests it to be synthetic. Osticioli and other researchers have compared natural lapis lazuli with synthetic ultramarine, suggesting that the former contains a large concentration of inclusions, while the latter is characterized by small ( 5 to $10 \mu \mathrm{m}$ in diameter) and uniformly sized particles [28, 29]. The blue pigment at the Lotso Residence exhibits the same features as shown in Fig. 8.

Yellow/orange-yellow layers Realgar and orpiment were found in the orange-yellow layer of GL-N-1 (earlier) and GL-W-3 (later) by Raman microscopy. This finding is consistent with the results of SEM-EDS. The two minerals are closely associated in the same deposits in nature and were probably not separated in the pigment-making process. Visually, the yellow paint over the black at the Lotso Residence seems lighter and has a colder tone, which has already pointed to a different type of pigment. The SEMEDS analysis detected neither As nor S, whereas the high concentration of $\mathrm{Pb}$ and $\mathrm{Cr}$ indicates the presence of chrome yellow $\left(\mathrm{PbCrO}_{4}\right)$, which was confirmed by Raman microscopy.

Green layers The XRD results of the green powder sample from earlier paintings of Gazhi Lhakang reveals a mix of malachite and brochantite $\left(\mathrm{Cu}_{4} \mathrm{SO}_{4}(\mathrm{OH})_{6}\right)$. Brochantite is not a common pigment but has been identified in the Thubchen Lakhang temple in Nepal by Mazzeo et al. [16], where brochantite is suggested to be an alteration product of malachite. For the later paintings, SEM-EDS shows that the green layers of GL-N-1 and GL-N-2 comprise $\mathrm{Cu}$, $\mathrm{Si}$, As, and $\mathrm{S}$. Hence, the green appeared to be malachite, which was mixed with realgar or orpiment when the green layer meets the red layer underneath. In samples from the Lotso Residence (LTS-E-3 and LTS-W-2), Cu and As, but no $\mathrm{S}$, were identified in the green. By Raman analysis, these layers were determined to be emerald green $\left(\mathrm{Cu}\left(\mathrm{C}_{2}\right.\right.$ $\left.\left.\mathrm{H}_{3} \mathrm{O}_{2}\right)_{2} \cdot 3 \mathrm{Cu}\left(\mathrm{AsO}_{2}\right)_{2}\right)$.

Black layer at the Lotso Residence In LTS-E-1, where pure black is used as the base color for the metallic lines, SEM-EDS analysis of the black pigments revealed a large amount of $\mathrm{C}$, which was confirmed by Raman microscopy. The pigment was identified as carbon black.

Metallic materials Metallic materials were observed at both Gazhi Lhakang and the Lotso Residence. SEM-EDS showed that a gold-silver alloy was used for the former site and copper for the latter. In Tibet, since the price of copper was much lower than that of gold, it was not uncommon (particularly in the modern period) to substitute genuine gold by imitation gold, which could be either copper or a copper-zinc alloy (brass) $[27,30]$. In the wall paintings at the Jokhang Monastery, a copper-zinc alloy was detected [31]. 
Table 2 Pigment composition of Gazhi Lhakang temple

\begin{tabular}{|c|c|c|c|c|c|c|c|c|}
\hline Location & Sample & \begin{tabular}{|l|}
$\begin{array}{l}\text { Surface } \\
\text { color }\end{array}$ \\
\end{tabular} & $\begin{array}{l}\text { Layer (from } \\
\text { upper to lower) }\end{array}$ & $\begin{array}{l}\text { SEM-EDS } \\
\text { main } \\
\text { element }\end{array}$ & Raman & $\begin{array}{l}\text { Possible } \\
\text { explanation }\end{array}$ & Cross-section $(200 \times)$ and test points & Cross-section $(500 \times)$ \\
\hline \multirow{9}{*}{$\begin{array}{l}\text { Early- } \\
\text { Gazhi } \\
\text { Lhakang } \\
\text { (north } \\
\text { wall) }\end{array}$} & \multirow[t]{5}{*}{ GL-N-1 } & \multirow[t]{5}{*}{ Golden } & $\begin{array}{l}\text { Metallic layer } \\
(1,2): 15 \mu \mathrm{m}\end{array}$ & $\mathrm{Au}, \mathrm{Ag}$ & & Gold-silver alloy & & \\
\hline & & & $\begin{array}{l}\text { Light-yellow } \\
\text { layer (3): } 60 \mu \mathrm{m}\end{array}$ & $\begin{array}{l}\mathrm{Fe}, \mathrm{Si}, \mathrm{Al}, \\
\mathrm{K}, \mathrm{Ca}, \mathrm{Mg}\end{array}$ & & Clay minerals & & \\
\hline & & & $\begin{array}{l}\text { Orange layer (4) } \\
20 \mu \mathrm{m}\end{array}$ & :S, As & $\begin{array}{l}\mathrm{As}_{4} \mathrm{~S}_{4} \\
\mathrm{As}_{2} \mathrm{~S}_{3}\end{array}$ & $\begin{array}{l}\text { Mix of realgar and } \\
\text { orpiment }\end{array}$ & & \\
\hline & & & $\begin{array}{l}\text { Light-yellow } \\
\text { layer (5): } 35 \mu \mathrm{m}\end{array}$ & $\begin{array}{l}\mathrm{Fe}, \mathrm{Si}, \mathrm{Al}, \\
\mathrm{K}, \mathrm{Ca}, \mathrm{Mg}\end{array}$ & & Clay minerals & & \\
\hline & & & $\begin{array}{l}\text { Red layer (6): } 13 \\
\mu \mathrm{m}\end{array}$ & $\begin{array}{l}\mathrm{Si}, \mathrm{Al}, \mathrm{Pt}, \\
\mathrm{Ca}, \mathrm{Fe}\end{array}$ & & Unidentified & & * \\
\hline & \multirow[t]{4}{*}{ GL-N-2 } & \multirow{4}{*}{$\begin{array}{l}\text { Golden } \\
\text { lines in } \\
\text { red base }\end{array}$} & Black layer & & & $\begin{array}{l}\text { Oil from the } \\
\text { candle burning }\end{array}$ & & \\
\hline & & & $\begin{array}{l}\text { Metallic layer } \\
(2): 13 \mu \mathrm{m}\end{array}$ & $\mathrm{Au}, \mathrm{Ca}$ & & Gold & & \\
\hline & & & $\begin{array}{l}\text { Red layer (3): } 33 \\
\mu \mathrm{m}\end{array}$ & $\mathrm{C}, \mathrm{O}$ & $\mathrm{HgS}$ & Cinnabar & & \\
\hline & & & $\begin{array}{l}\text { Light-yellow } \\
\text { layer (4): } 80 \mu \mathrm{m}\end{array}$ & $\mathrm{Si}, \mathrm{Al}, \mathrm{K}$ & & Clay minerals & & \\
\hline \multirow{13}{*}{$\begin{array}{l}\text { Late- } \\
\text { Gazhi } \\
\text { Lhakang } \\
\text { (west } \\
\text { wall) }\end{array}$} & \multirow[t]{3}{*}{ GL-W-1 } & \multirow{3}{*}{$\begin{array}{l}\text { Red } \\
\text { with } \\
\text { some } \\
\text { green }\end{array}$} & $\begin{array}{l}\text { Green layer (2): } \\
118 \mu \mathrm{m}\end{array}$ & $\begin{array}{l}\mathrm{As}, \mathrm{Si}, \mathrm{S}, \\
\mathrm{Cu}\end{array}$ & & $\begin{array}{l}\text { Mix of Malachite } \\
\text { and } \\
\text { realgar/orpiment }\end{array}$ & & \\
\hline & & & $\begin{array}{l}\text { Red layer (1): } 82 \\
\mu \mathrm{m}\end{array}$ & $\mathrm{Fe}, \mathrm{Si}, \mathrm{Al}$ & $\begin{array}{l}\mathrm{Fe}_{2} \mathrm{O}_{3} \\
\mathrm{As}_{4} \mathrm{~S}_{4}\end{array}$ & $\begin{array}{l}\text { Mix of iron red } \\
\text { and realgar }\end{array}$ & & \\
\hline & & & $\begin{array}{l}\text { Light-yellow } \\
\text { layer (3) }\end{array}$ & $\mathrm{Ca}, \mathrm{Si}, \mathrm{Al}$ & & Clay minerals & $\Leftrightarrow$ & \\
\hline & \multirow[t]{3}{*}{ GL-W-2 } & \multirow[t]{3}{*}{ Green } & $\begin{array}{l}\text { Green layer (2): } \\
149 \mu \mathrm{m}\end{array}$ & \begin{tabular}{|l|}
$\mathrm{Si}, \mathrm{As}, \mathrm{S}$, \\
$\mathrm{Cu},($ no $\mathrm{Na}$ \\
or $\mathrm{Al}$ )
\end{tabular} & $\mathrm{As}_{2} \mathrm{~S}_{3}$ & $\begin{array}{l}\text { Mix of Malachite } \\
\text { and orpiment }\end{array}$ & & \\
\hline & & & $\begin{array}{l}\text { Red layer (5): } 80 \\
\mu \mathrm{m}\end{array}$ & $\mathrm{Si}, \mathrm{Al}, \mathrm{Fe}$ & & Iron red & & \\
\hline & & & $\begin{array}{l}\text { Light-yellow } \\
\text { layer (3) }\end{array}$ & $\begin{array}{l}\mathrm{Si}, \mathrm{Al}, \mathrm{Ca}, \\
\mathrm{Fe}, \mathrm{K}, \mathrm{Mg}\end{array}$ & & Clay minerals & & \\
\hline & \multirow[t]{4}{*}{ GL-W-3 } & \multirow{4}{*}{\begin{tabular}{|l|} 
Yellow \\
with \\
some \\
blue
\end{tabular}} & $\begin{array}{l}\text { Blue layer (5): } \\
28 \mu \mathrm{m}\end{array}$ & $\mathrm{Ca}, \mathrm{Si}, \mathrm{Mg}$ & & Unidentified & & \\
\hline & & & $\begin{array}{l}\text { Orange layer (4) } \\
55 \mu \mathrm{m}\end{array}$ & :As, S & $\begin{array}{l}\mathrm{As}_{4} \mathrm{~S}_{4} \\
\mathrm{As}_{2} \mathrm{~S}_{3}\end{array}$ & $\begin{array}{l}\text { Mix of realgar and } \\
\text { orpiment }\end{array}$ & & \\
\hline & & & $\begin{array}{l}\text { Red layer (2): } 49 \\
\mu \mathrm{m}\end{array}$ & $\mathrm{Si}, \mathrm{Fe}$ & & Iron red & & \\
\hline & & & $\begin{array}{l}\text { Light-yellow } \\
\text { layer (1) }\end{array}$ & $\begin{array}{l}\mathrm{Si}, \mathrm{Fe}, \mathrm{Al}, \\
\mathrm{Ca}, \mathrm{Mg}\end{array}$ & & Clay minerals & & \\
\hline & \multirow[t]{3}{*}{ GL-W-4 } & \multirow[t]{3}{*}{ Blue } & $\begin{array}{l}\text { Blue layer (1): } \\
56 \mu \mathrm{m}\end{array}$ & $\begin{array}{l}\mathrm{Cu}, \mathrm{Fe},(\text { no } \\
\mathrm{Na}, \mathrm{Al}, \mathrm{Cl} \text { or } \\
\mathrm{S})\end{array}$ & & Azurite & & \\
\hline & & & $\begin{array}{l}\text { Red layer }(2,3): \\
50 \mu \mathrm{m}\end{array}$ & $\mathrm{Si}, \mathrm{Fe}$ & & Iron red & & \\
\hline & & & $\begin{array}{l}\text { Light-yellow } \\
\text { layer (4) }\end{array}$ & $\begin{array}{l}\mathrm{Si}, \mathrm{Fe}, \mathrm{Al}, \\
\mathrm{Ca}, \mathrm{Mg}\end{array}$ & & Clay minerals & & \\
\hline
\end{tabular}

\section{Painting techniques \\ The use of paper}

In the earlier phase of Gazhi Lhakang, the paper serves as the actual support of the large-figure paintings. Based on observations, Kalsang Norbu [4] suggests that the paper was glued to the wall. Kalsang Norbu notes that painting on paper allows for richer details in the depiction, but it was difficult to estimate the amount of glue. A similar "paperhanging" technique was frequently used for caihua (彩画), which is a painted architectural decoration, in
China during the Ming and Qing dynasties (1368-1912). This technique has been found in the Cining Palace in Beijing and the Kumbum Monastery, which is one of the major Tibetan Buddhist sites in Qinghai [32, 33]. In the case of Kumbum, the procedure is described as follows: artisans (1) decide the dimensions of the painting area, (2) paste two layers of paper together, (3) complete the painting on the paper, (4) apply a layer of gesso on the wooden wall, (5) paste the painting to the gesso layer, and (6) apply an oil finishing layer to the surface. 
Table 3 Pigment composition of Lotso residence

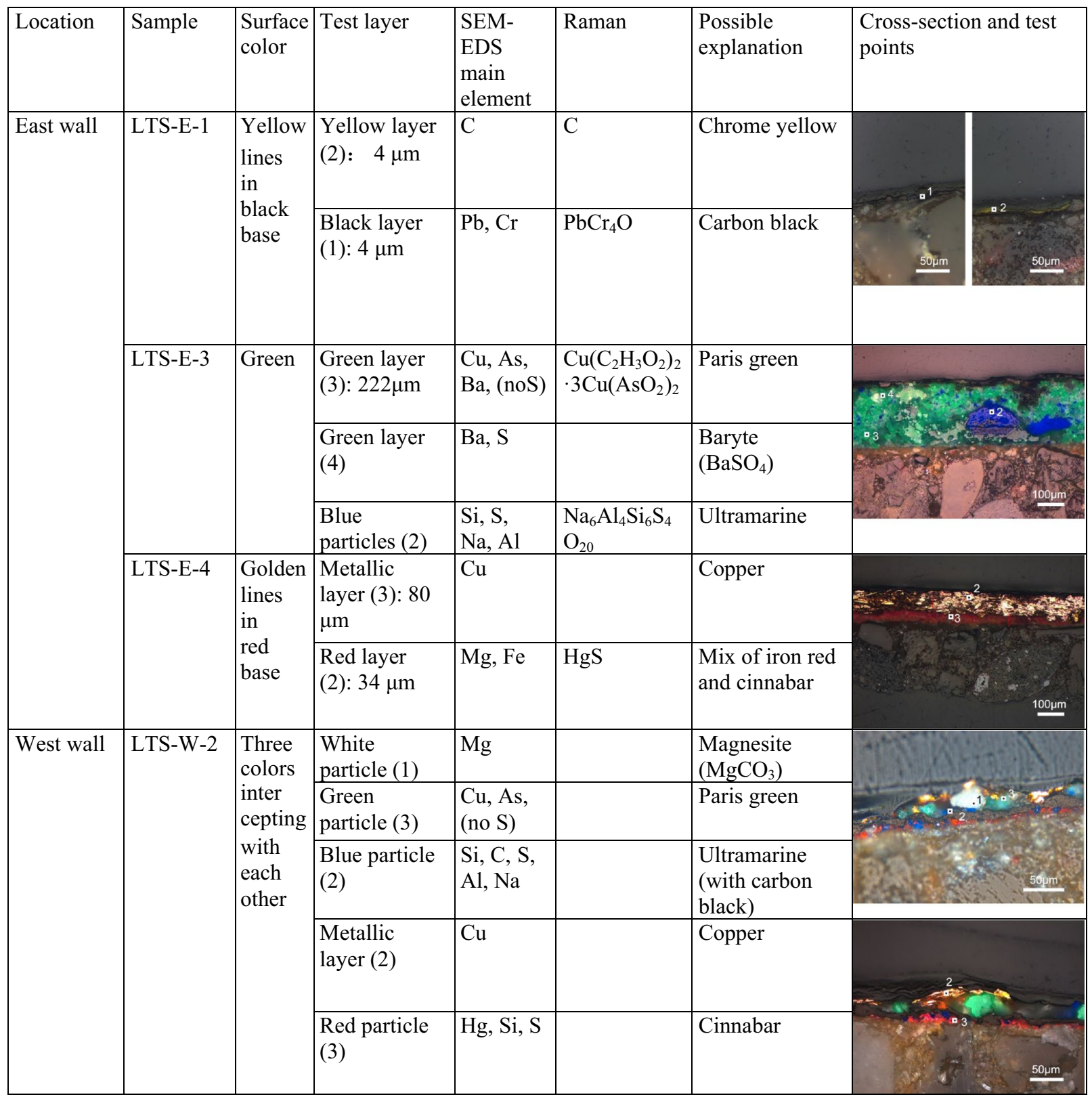

Although this practice was not commonly identified in murals, Wang et al. [25] found a silk layer between the coating and the white powder layer in the wall painting of the pilgrimage-corridor in the Jokhang Monastery. This layer was possibly made by a similar process as that used in Gazhi Lhakang, only with more precious material.

Techniques of powder embossing, gilding, and gold outlining Powder embossing, usually followed by gilding, has been identified as one of the traditional painting techniques in Tibet. This method is comparable to the method used in
Beijing during the Qing Dynasty (1636-1912), wherein chalk and binding media are mixed in a certain ratio, filled into a container, and squeezed out through a small opening [17, 34]. An orange pigment layer (as seen at Gazhi Lhakang) is often applied before gilding to increase the brightness. Then, a metal powder or foil (either genuine gold or imitation gold) is pasted on the embossed outlines. The combination of the two techniques commonly appears on important Buddhist figures, especially on their jewelry, halos, and sacred objects $[17,18]$. Scholars have found the use of this combination of techniques 


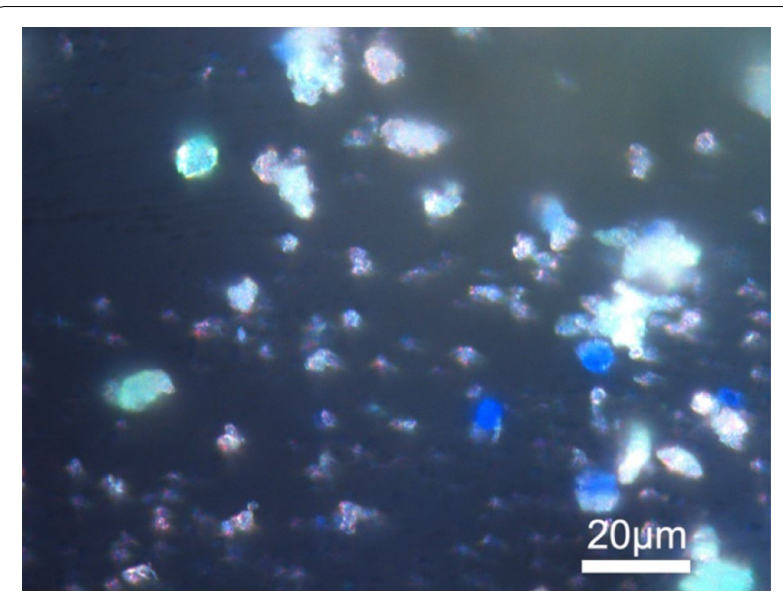

Fig. 8 Morphology of the blue particles (1000x)

at a few significant Buddhist sites in Tibet, such as the Potala Palace [9] and Drepung Monastery [12]. In Nepal, Mazzeo et al. [16] found a special technique that they termed gilded "pastiglia." They suggest that the decoration was prepared as small tablets and glued to the painting surface, but the resulting appearance might be similar to the powder-embossed examples in Tibet.

Gold (or silver) outlining is also widely used for important wall paintings, particularly for jewelry and garments of Buddhist deities and sometimes in landscapes $[17,18]$. The practice of painting lines over a red (as seen at Gazhi Lhakang) or black (as seen at the Lotso Residence) background also appears in thangkas [27]. The process of producing a metal "ink" involves mixing the metal powder with glue material. The grinding of metal requires using a stone or a special liquid medium to prevent the particles from adhering to each other [27].

\section{Implication of dates}

The identification of synthetic pigments at the Lotso Residence dates the paintings to the mid-nineteenth century or later, although the painting style emerged earlier. Emerald green was first produced and sold as a commercial pigment in Europe in 1814. Lead chrome was first synthesized and recognized as a potential pigment by French chemists in 1804, and its mass production started around 1814-1816. Synthetic ultramarine has been used as a substitute for lapis lazuli in Italy since the late nineteenth century [35]. In China, artificial pigments have been reported in the decoration of wooden architecture and paintings from the Qing Dynasty. For example, emerald green was found in the decorative paintings of Zhendu Men in the Palace Museum [36]. In Tibet, all three artificial pigments were found in Jokhang [11], and emerald green was identified in Drepung [37]. Scholars have also identified the application of these pigments in thangka paintings in the late nineteenth and early twentieth centuries [27, 38]. Given the role of Gyantse on the trade route, it is likely that synthetic pigments were imported from India.

The mineral pigments used at Gazhi Lhakang, such as cinnabar, iron red, orpiment, realgar, azurite, and malachite, can be mined locally in Tibet [26]. However, these pigments are still in use today and do not necessarily indicate an earlier date of the paintings.

\section{Conclusion}

In this study, the complementary use of optical microscopy, SEM-EDS, Raman spectroscopy, and XRD allowed for the identification of the minerals contained in the murals at Gazhi Lhakang and the Lotso Residence in Gyantse, Tibet. The coating and ground layers varied from the description in the literature, while the basic materials are still clay and sand. The identified natural and synthetic pigments are consistent with many previous findings at other sites in Tibet and Nepal.

The earlier murals of Gazhi Lhakang exhibit a complicated stratigraphy, wherein the large Buddhist images were painted on paper, and powder embossing and gilding were applied. Traditional mineral pigments and genuine gold were used, representing the wealth of the aristocratic family. However, the later paintings at the same building were simplified in terms of ground treatment and painting techniques. At the Lotso Residence, which is a nonreligious building that still holds significance, the gilding techniques enhanced the appearance of the shrine room. On the other hand, the use of synthetic pigments and imitation gold (copper) implies a relatively low cost.

The presence of copper at the Lotso Residence requires attention if the murals are to be cleaned. Usually, the darkened surface of Tibetan murals is the result of burning oil lamps. In the case of the Potala Palace, the conservators used an alkalic solution to remove the oil and then citric acid to neutralize it [9]. This method is not appropriate for copper, and a neutral chemical will be required for cleaning.

\section{Acknowledgements \\ Not applicable.}

\section{Authors' contributions}

$X Y$ and $X J$ designed the work, performed the acquisition and analysis of data, and drafted the paper. XY and TY interpreted the results and revised the paper. YC conceived the work and revised the paper. All authors have contributed to, seen and approved the manuscript. All authors read and approved the final manuscript.

\section{Funding}

This work was financed by the National Natural Science Foundation of China (NSFC) within the scope of project 51678355. 


\section{Availability of data and materials}

The datasets used and analyzed during the current study are available from the corresponding author on reasonable request.

\section{Competing interests}

The authors declare that they have no competing interests.

Received: 25 December 2018 Accepted: 11 June 2019

Published online: 20 June 2019

\section{References}

1. Li R. A Tibetan aristocratic family in eighteenth-century Tibet: a study of Qing-Tibetan contact [dissertation]. Cambridge: Harvard University; 2002. p. 325.

2. Doring Tendzin Peljor. The biography of Rdo ring family. Beijing: Chinese Tibetology Press; 1995. (originally in Tibetan, translation in Chinese)

3. Zheng Y. From Gzhis-ka Pala to Jiangzi Reginal Gzhis-ka Architecture. Archit Hist. 2008;00:144-56 (in Chinese).

4. Kalsang Norbu. A study of the wall painting in Gazhi Lhakang [master's thesis]. Lhasa: Tibet University; 2009. p. 77. (in Tibetan).

5. Jackson D. A history of Tibetan painting: the great Tibetan painters and their traditions. Wien: Verlag der Österreichischen Akademie der Wissenschaften; 1996.

6. Gyantse county annals editing group. Gyantse county annals. Beijing: China Tibetology Press; 2004 (in Chinese).

7. Wang $X$. Exploration and practice of the methodology for wall painting conservation based upon principles for the conservation of heritage sites in China. Dunhuang Res. 2011;06:1-7+125. https://doi. org/10.13584/j.cnki.issn1000-4106.2011.06.008. (in Chinese).

8. Wang W, Ma Z, Yu Z, Zhao L, Li S, Sun H, Fu Y. An analysis on the materials of murals in Potala Palace, Norbuglinkha and Sa-Skya Monastery, Tibet. Dunhuang Res. 2002;6:78-84. https://doi.org/10.13584/j.cnki. issn1000-4106.2002.06.013 (in Chinese).

9. Li Z, Wang W, Wang X, Chen J, Qiangba G. Report on wall painting conservation and restoration project of Potala Palace, Tibet. Beijing: Cultural Relics Press; 2008 (in Chinese)

10. Li Z, Wang W, Yang T, Ma Z, Chen J, Ma Y. Report on wall painting conservation and restoration project of Norbulingka Palace, Tibet. Beijing: Cultural Relics Press; 2015 (in Chinese).

11. Li Z, Wang L, Ma Q, Mei J. A scientific study of the pigments in the wall paintings at Jokhang Monastery in Lhasa, Tibet, China. Heritage Sci. 2014;2(1):21.

12. Qi N, Guo H, Wang LD. A study on the materials and techniques of the wall paintings in the circumambulation corridor in the assembly hall, Drepung Monastery. China Tibetol. 2014;03:170-175 + 209. (in Chinese)

13. Yong $L$, Shiwei W. Material analysis of the wall paintings in Xialu Temple, Tibet Autonomous Region, China. Stud Conserv. 2014;59(5):314-27.

14. Wang L, Guo H. Studies on the technique of wall paintings at multi-door Chorten in Palcho Monastery. China Tibetol. 2013;4:174$180+205$. (in Chinese).

15. Wang L, Guo H. A study on the workmanship and materials of Palkor Monastery Ren Ding dratsang Wall painting in Gyangze County Tibet. China Cult Heritage Sci Res. 2016;01:85-9 (in Chinese).

16. Mazzeo R, Baraldi P, Lujan R, Fagnano C. Characterization of mural painting pigments from the Thubchen Lakhang temple in Lo Manthang, Nepal. J Raman Spectrosc. 2004;35(8-9):678-85.

17. $\mathrm{Xu}$ J. The procedure and method of wall painting in Tibetan monastery. Tibetan Art Stud. 1993;2:50-5 (in Chinese)

18. Wang $X$. Introduction of the techniques of traditional Tibetan wall paintings. Art Educ Res. 2012;23:11-2 (in Chinese).

19. Chen J, Zhang X. The Sanskrit letters written in Ranjana script as decoration in Han Chinese Buddhist temples during the Ming and Qing dynasties. Art Res. 2015;03:56-63. https://doi.org/10.13318/j.cnki. msyj.2015.03.011 (in Chinese).

20. Herrle P. Tibetan Houses: vernacular architecture of the himalayas and environs. Basel: Birkhäuser; 2017.
21. Zuixiong $L$, Linyi $Z$, Li L, Jinua W. Research on the modification of two traditional building materials in ancient China. Heritage Sci. 2013;1(1):27

22. Alexander A. The Temples of Lhasa: Tibetan Buddhist architecture from 7th to 21st centuries. Chicago: Serindia Publications; 2005.

23. Wang $L$, Guo $H$. Studies on the wall painting techniques of the main assembly hall at the Palkor Monastery. China Tibetol. 2016;02:171-4 (in Chinese).

24. Zhao J. Several considerations on the art and the conservation and restoration of Tibetan wall painting. Dunhuang Res. 2006;04:98$101+121$. https://doi.org/10.13584/j.cnki.issn1000-4106.2006.04.016. (in Chinese).

25. Wang L, Li Z, Zhang X, Mei J, Ma Q. Studies on wall painting techniques at Jokhang temple, Lhasa, Tibet, China. Sci Conserv Archaeol. 2014;26(4):84-92. https://doi.org/10.16334/j.cnki.cn311652/k.2014.04.014 (in Chinese)

26. Danba R, Ngawang, Sonam R, Chime D. The history and the technological study of traditional tibetan painting pigment. China Tibetol. 2003;01:65-72

27. Jackson DP, Jackson JA. Tibetan Thangka painting: methods and materials. London: Serindia Publications; 1984

28. Song Y, Gao F, Nevin A, Guo J, Zhou X, Wei S, Li Q. A technical study of the materials and manufacturing process used in the Gallery wall paintings from the Jokhang temple, Tibet. Heritage Sci. 2018;6(1):18.

29. Osticioli I, Mendes NF, Nevin A, Gil FP, Becucci M, Castellucci E. Analysis of natural and artificial ultramarine blue pigments using laser induced breakdown and pulsed Raman spectroscopy, statistical analysis and light microscopy. Spectrochim Acta A Mol Biomol Spectrosc. 2009;73(3):525-31.

30. Tashi W, She W, Hu H. Tibetan metal cultural crafts (IV). Tibet Art Stud. 1993;Z1:64-9 (in Chinese).

31. Wang L. Studies on the colors and the value of wall paintings at the Jokhang Monastery, Tibet. Res China's Front Archaeol. 2014;02:329-41 (in Chinese)

32. Pei Q, Sun Y, Song Y, Wang F. Research on the painting techniques of architectural decoration at the mansion of Jamyang Rinpoche of the Kumbum Monastery. Sci Conserv Archaeol. 2016;28(03):93-101. https ://doi.org/10.16334/j.cnki.cn31-1652/k.2016.03.016 (in Chinese).

33. Li Y, Liu M. A study of the materials and techniques used in the polychrome ceiling decoration of the Linxi Pavilion in the garden of the Cining Palace. Palace Mus J. 2018;06:45-63 + 159. https://doi. org/10.16319/j.cnki.0452-7402.2018.06.004. (in Chinese).

34. Zhu T, Li T, Liu N, Chen J, Huang H, Fu Q, Zhang S. Hexi painting on Xitian Fanjing, a Qing imperial Buddhist temple in Beijing, China: technology revealed by analytical approaches (an initial report). Heritage Sci. 2016;4(1):42.

35. Eastaugh N, Walsh V, Chaplin T, Siddall R. Pigment compendium: a dictionary and optical microscopy of historical pigments. Amsterdam: Butterworth-Heinemann; 2008.

36. Cheng $X$, Xia Y, Ma Y, Lei Y. Three fabricated pigments (Han purple, indigo and emerald green) in ancient Chinese artifacts studied by Raman microscopy, energy-dispersive X-ray spectrometry and polarized light microscopy. J Raman Spectrosc. 2007;38(10):1274-9.

37. Chen X, Yang Q. Micro-Raman spectroscopy study of three green pigments containing copper and arsenic. Sci Conserv Archeol. 2015;27(03):84-9. https://doi.org/10.16334/j.cnki.cn311652/k.2015.03.015 (in Chinese).

38. Mass J, Huang J, Fiske B, Shaftel A, Zhang X, Laursen R, et al. Thangka production in the $18^{\text {th }}-21$ st centuries: documenting the introduction of non-traditional materials into Himalayan painting practice. In: Proceedings of the forum on the conservation of Thangkas, SPECIAL SESSION of the ICOM-CC 15th triennial conference, New Delhi, India, September 26, 2008, edited by Mary Ballard and Carole Dignard, ICOMCC, 2009. p. 108-117.

\section{Publisher's Note}

Springer Nature remains neutral with regard to jurisdictional claims in published maps and institutional affiliations. 